\title{
AMBUSH MARKETING: THE KULULA.COM PERSPECTIVE
}

by $R$ Kgobokoe*

\section{Overview}

Ambush Marketing is often described as a type of 'parasitic marketing.' However, before we look into ambush marketing one has to consider the essence of marketing and more specifically, advertising. The purpose of advertising is essentially to create brand awareness, by somehow making the public aware of the product you offer as a company or firm. Sponsorship is a mechanism through which brand awareness can be created. Sponsorship can be defined as a commercial arrangement, whereby a sponsor pays a certain sum of money (a sponsorship fee) or provides certain products, services or other facilities to the sponsored party, in return for which, the sponsor is granted certain rights of association with the sponsored party. ${ }^{1}$ What better way to create awareness than at a major global event? By paying the event organisers an agreed amount, they associate your product with their event. For instance, First National Bank (FNB) agree to sell the Fédération Internationale de Football Association (FIFA) world cup tickets at their branches across the country without sharing in any of the profits, they may not be generating any money from actual ticket sales but they get thousands of people coming in and out of their branches daily, thus more importantly, creating band awareness. ${ }^{2}$ Sponsors should be protected by organisers from unofficial non-sponsors, but to what extent? While the law should attempt to safeguard the investments of sponsors of events, we should not be unreasonable in our attempts. Laws and regulations should be applied with at least a modicum of sanity and those responsible for their enforcement should avoid adopting a dictatorial approach.

\section{Ambush Marketing}

The Advertising Standards Authority (ASA) in its sponsorship code defines ambush marketing as:

Reba Kgobokoe, final year LLB student, University of Pretoria.

S Gardiner Sports Law 2nd Ed (2001) 507.

This hypothetical scenario might not be too far fetched. 
The attempt of an organisation, product or brand to create the impression of being an official sponsor of an event or activity by affiliating itself with that event or activity without having paid the sponsorship rights-fee or being a party to the sponsorship contract. ${ }^{3}$

In layman's terms this simply means that ambush marketing occurs when an organisation claims association to an event on which it did not, legally, spend a cent to claim such association.

In broad terms, ambush marketing is said to take two forms, namely: Association and Intrusion.

\subsection{Association}

The ambush marketer misleads the public into thinking that he is an authorised sponsor or contributor associated with an event. ${ }^{4}$ 'Association' occurs through the use of the insignia of the event or insignia which are similar to such insignia which may cause confusion, or by misrepresenting that the marketer or his product is associated with the event.

\subsection{Intrusion}

The ambush marketer does not seek to suggest a connection with the event but rather to give his own brand or other insignia exposure through the medium of the publicity attracted by the same event without the authorisation of the event organiser. ${ }^{5}$ Ambush marketing by intrusion will include the following examples:

(a) A marketer who markets his product or brand by creating a promotional competition in which he makes reference to an event which has been sponsored.

(b) The advertising of a brand or product outside or in close vicinity to a stadium where an event which is sponsored is taking place.

(c) The flying of an airplane or blimp with advertising on it over a stadium at which a sponsored sporting event is being held.

In both association and intrusion the aim is to use a sponsored event to market a product or brand without bearing the financial costs.

There are also various categories of ambush marketing within this broad framework, including: 6

http: / /www.asasa.org.za (accessed 5 May 2010).

O Dean 'Ambush marketing' (2000) June De Rebus 24.

Dean (n 4 above) 24.

There are various other forms of ambush marketing however the focus of this discussion is advertising. 


\subsubsection{Unauthorised use of intellectual property rights}

An example of this could be 'Passing-off'. Passing off occurs when a competitor uses the trademarks of his opponent in order to create the impression that his performance is similar to or associated to the already well-known performance of his opponent thus deceiving and influencing consumers to accept his performance. ${ }^{7}$

\subsubsection{Broadcast sponsorship}

This could simply be done by broadcasting an event without the rights.

\subsubsection{Advertising}

For example, the bulk purchase of advertising in selected media in and around an event by an unofficial supplier seeking to take advantage of the name and reputation of the event is relatively straight forward: such advertising need not make specific reference to the event, but just to the particular sport or activity involved. In a recent advertisement, Kulula.com advertised itself as the 'unofficial carrier during the: you know what!' Kulula.com did not make any specific reference to the world cup, but an association was obvious ... during the period of the 'YOU KNOW WHAT'. Such reference is unlikely to infringe any intellectual property right but can definitely result in a high identification on the part of the public with the event in question.

The 2002 World Cup in football was beset with ambush marketing incidents. FIFA ${ }^{8}$ is reliant on revenue from exclusive sponsorships. Coca Cola was one of the sponsors of the World Cup. A television commercial by its non-sponsoring competition, PepsiCo, featured leading footballers playing against a world cup backdrop featuring a cohort of sumo wrestlers. With the World Cup having come to South Africa in 2010, FIFA took the opportunity to set an example and thus set a precedent against any would be ambush marketers. An application was brought to the High Court, in which interdicts against Eastwood Tavern were sought. These interdicts were sought on the basis of:

(i) Infringing a registered trademark namely 'World Cup 2010,' 'South Africa 2010' and 'Twenty Ten South Africa';

(ii) Passing off under the common law;

HB Klopper \& P Van der Spuy Law of Intellectual Property (2008) 106. Federation International de Football Association. 
(iii) The violation of section 15A of the Merchandise Marks Amendment Act ${ }^{9}$ and section 9(d) of the Trade Practices Amendment Act. ${ }^{10}$

Eastwood Tavern is a restaurant located in the vicinity of one of the 2010 Soccer World Cup Stadiums being Loftus in Pretoria. The restaurant's front signature had the words 'World Cup 2010' emblazoned on it along with the flags of a number of participating countries.

The South African parliament amended its trade practices legislation to respond to the anticipated problem of ambush marketing. The new law prohibits commercial statements that suggest or imply a contractual or other connection with a sponsored sports event or a person sponsoring an event. Parliament also amended merchandise marks legislation specifically to prohibit infringement of intellectual property rights in connection with (before, during and after) officially protected events. Sanctions for violation of either law include stiff fines and imprisonment of offenders.

These legislations were applied successfully in the case of FIFA v Metcash Trading Africa (Pty) Ltd. ${ }^{11}$ Metcash produced a lollipop product which was marketed as '2010 Pops' and featured images of soccer balls similar in design to the official ball used by FIFA in a past tournament, together with the South African flag. The court found in favour of FIFA, finding that Metcash intended its lollipop product to be associated with the 2010 FIFA World Cup and to derive a special promotional benefit from the event.

\section{Ambush Marketing and the Constitution (The Kulula.com perspective)}

Ambush marketing is not ordinarily illegal insofar as it does not involve trademark piracy. The Kulula.com advertisement has carefully avoided any trademark violation. They clearly state that they are 'unofficial', they do not make any blatant affiliation with FIFA, instead they seem to be looking to be operative like any business would during the world cup. Ambush marketing legislation can not certainly be looking to stifle the growth of non-associated organisations during major events. If one was to consider Section 16 of the Constitution, ${ }^{12}$ in $16(1)$ it clearly states that everyone has the right to freedom of expression, which includes: (a) freedom of the press and other media; (b) freedom to receive or impart information

11 FIFA v Metcash Trading Africa (Pty) Ltd (2009) JOL 24382 (GNP).

12 The Constitution of the Republic of South Africa, 1996. 
or ideas; (c) freedom of artistic creativity; and (d) academic freedom and freedom of scientific research.

It should always be borne in mind that these rights are guaranteed by the Constitution, even though some of the limitations of ambush marketing may be justified in terms of the section 36 limitation clause in the Constitution, it is important that we should avoid getting carried away by the whole ambush marketing phenomenon. The whole country should not come to a halt all in the name of the World Cup. Sponsoring organisations should have their sponsorships protected but surely strong competition should still be allowed to exist. It is important not to allow organisations such as FIFA to intimidate local business and stifle free trade. If the highest bidding sponsor is guaranteed exclusive protection at the expense of smaller non-associated organisations then are not we stunting growth and building monopolies. In an economy which notoriously favours the rich, should we not rather see the FIFA world cup as an opportunity to spread the wealth instead of allowing FIFA and big business to continue its parasitic dominance? The official beer of the World Cup was Budweiser, this was the case in Germany 2006, and they also have the rights to the next event in 2014. Budweiser is not even a South African beer. What is the point of even having a World Cup in South Africa? Granted many jobs were created during the intense construction in and around the major cities, but what about the loss in sales for companies like SAB miller? There are even marketing exclusion zones surrounding stadia, the 2010 FIFA World Cup South Africa Special Measures Act, 2006 has made specific provision for the establishment of such areas. This will ensure that the bigger organisations become immortal while the smaller ones eventually disappear. This is surely an opportunity for the Competition Commission to intervene.

There seems to be a trend in many jurisdictions to address the problem of ambush marketing by means of specialised legislation. This is driven by the realisation that ambush marketing is causing harm, not only to legitimate sponsors of events but also to sports bodies as well as the economies of regions or countries. FIFA works all year and all around the world to ensure that its official trademarks and other intellectual property rights are properly protected and enforced. The Rights Protection Programme is aimed primarily at tackling organised ambush marketers, counterfeiters and unauthorised traders, all of whom seek to profit from an event to which they have not contributed. In South Africa the Official Marks are protected by the Trade Marks Act, ${ }^{13}$ the Copyright Act, ${ }^{14}$ the Counterfeit Goods Act, the common law delict of passing off in 
addition to other specific statutory provisions such as the Trade Practices Act and the Merchandise Marks Act. It is fair to combat nonofficial sponsors, but prohibitions should not be aimed at entrenching monopolies. FIFA has made government divert development money into fancy stadiums, and at the same time local business had to give up all sorts of rights during the world cup. Taking that into consideration, ambush marketing regulation should be done with a little common sense. Companies such as Kulula.com, should still be able to advertise their competitive prices to the huge foreign contingent that was in South Africa during the event, measures should obviously be put in place to control any form of 'parasitic advertising' but at the end of the day, the World Cup coming to South Africa is meant to have far reaching benefits for everyone. These are the sort of ideals our Constitution was founded upon: 'Better life for ALL!'15 